\title{
Improvement of Air Transport Environmental Safety by Implementing Alternative Jet Fuels
}

\author{
A.V. Yakovlieva*, S.V. Boichenko* and J. Zaremba** \\ * National Aviation University, Faculty of Environmental Safety, Engineering and Technologies, Kyiv, Ukraine \\ ** The University of Security Management in Košice, Slovakia \\ anna.yakovlieva@nau.edu.ua, chemmotology@ukr.net, jaroslav.zaremba@vsbm.sk
}

\begin{abstract}
The study is devoted to evaluation of exhaust gases emissions from aircrafts using conventional oil-derived jet fuel and alternative jet fuels, obtained by blending of conventional fuel with plant oil bio-additives. The evaluation was done by calculation of emission indexes of carbon dioxide, water vapor, sulfur oxide and nitrogen oxide and calculation of emission levels of each pollutant in a result of one standard landing - take-off cycle. In a result of the study it was found that samples of alternative jet fuels blended with plant oil bio-additives are characterized by lower emission level comparing to conventional jet fuels. These alternative jet fuels may also provide reduction of total emissions levels. Thus it was concluded that application of alternative jet fuels containing plant oil bio-additives may contribute to improvement of environmental safety of modern air transport.
\end{abstract}

\section{INTRODUCTION}

Today development of modern society consequently causes growth of air transport sector for providing passenger and cargo transportation. The world volume of aircraft transportation increases on 4-5\% annually [1]. Along with providing human needs, transport provides an intensive negative load on environment being responsible for $23 \%$ of world energy-related greenhouse gases emissions with about $2 \%$ from aviation. Over the past decade, transport's and aviation's in particular, greenhouse gases emissions have increased at a faster rate than any other energy using sector. Rising of air traffic causes the need in improvement of fuel efficiency and decreasing exhaust gases emissions from aircrafts. Numerous states around the world took a responsibility for creating conditions for safe and effective flights according to standards and practices recommended by ICAO. Countries- EU members are planning to reduce by 2030 levels of greenhouse emissions by $40 \%$ comparing to the level of 1990 [2, 3]. One of the main instruments for reaching this aim is implementing and using of alternative fuels for aviation. Today implementation of alternative jet fuels (JF) is considered as a measure for providing environmental safety of air transport along with ensuring its energy needs.

\section{ANALYSIS OF PREVIOUS STUDIES}

The main products of fuels, including JFs, combustion are $\mathrm{CO}_{2}$ and $\mathrm{H}_{2} \mathrm{O}$. Fuels production is connected with extraction of fossil fuels from Earth's interior and it leads to increase of total $\mathrm{CO}_{2}$ amount in the atmosphere [4]. As a result, we observe intensification of the global greenhouse effect on our planet. Except $\mathrm{CO}_{2}$ aircraft's emissions contain number of substances, which negatively influence on environment. Generally, aircrafts exhaust gases contain about 200 pollutants including $\mathrm{CO}_{2}, \mathrm{SO}_{x}$, $\mathrm{CH}_{4}, \mathrm{CO}$, soot, $\mathrm{NO}_{x}$, unburned hydrocarbons etc. Quantitative and qualitative composition of aircrafts emissions determines environmental properties of JFs, which are determined by the quality of feedstock used for JFs production, typically crude-oil [5].

The special attention to the question of improving of environmental safety of civil aviation is traditionally paid by ICAO (International Civil Aviation Organization). It considers production and use of alternative JFs as one of the most promising measures to reduce carbon dioxide and other exhaust gases emissions. This idea includes closed life-cycle of carbon dioxide starting from the process of fuel production to its combustion.

Significant progress in the development and deployment of alternative aviation fuels has been achieved over the last decades. During this time numerous technologies for alternative JFs production have been developed using great variety of feedstock (starting from natural gas and coal and up to plant oils and microalgae).

Thus the purpose of this study is to evaluate levels of exhaust gases (carbon dioxide in particular) from alternative JFs and estimate its efficiency for improvement of air transport environmental safety.

It is well known that qualitative and quantitative composition of aircrafts' emissions is determined by construction and efficient operation of jet engine (JE) and also environmental properties of JF, which in its turn are determined mainly by containing in them heteroatomic compounds such as sulfur [6]. Sulfur compounds influence on the content of sulfur oxides in exhaust gases of aircraft and consequently on their toxicity. The presence of aromatic hydrocarbons in JFs is an important indicator in assessing its environmental properties. Policyclic aromatic compounds are the source of soot in exhaust gases of aircrafts $[6,7]$.

For emissions estimation purposes, ICAO has defined a specific reference landing - take-off (LTO) cycle below

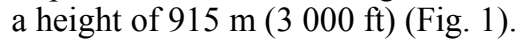




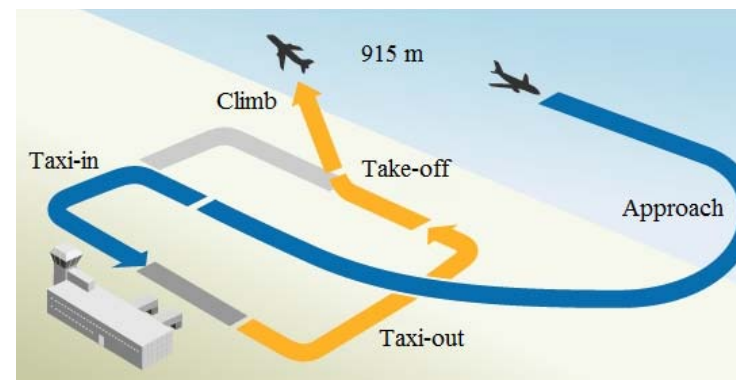

Figure 1. The ICAO landing and take-off cycle [6]

This cycle consists of four modal phases chosen to represent approaching, taxiing/idling, take-off and climbing and is a much simplified version of the operational flight cycle (Table 1).

TABLE I.

REFERENCE LTO CYCLE OF AN AIRCRAFT [6]

\begin{tabular}{c|l|c|c}
\hline No & \multicolumn{1}{|c|}{ LTO phase } & $\begin{array}{c}\text { Duration of } \\
\text { LTO phase, } \\
\text { min }\end{array}$ & $\begin{array}{c}\text { Relative } \\
\text { engine } \\
\text { thrust, } \%\end{array}$ \\
\hline 1 & Take-off & 0.7 & 100 \\
\hline 2 & Climb up to height $915 \mathrm{~m}$ & 2.2 & 85 \\
\hline 3 & $\begin{array}{l}\text { Approach and landing from } \\
\text { height 915 m }\end{array}$ & 4.0 & 30 \\
\hline 4 & Taxiing and ground idling & 26.0 & 7 \\
\hline
\end{tabular}

This reference emissions LTO cycle is intended to address aircraft operations below the atmospheric mixing height or inversion layer. While the actual mixing height can vary from location to location, on average it extends to

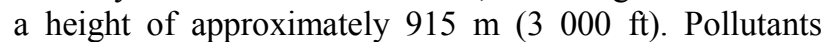
emitted below the mixing height can potentially have an effect on local air quality concentrations, with those emitted closer to the ground having possibly greater effects on ground level concentrations $[8,9]$.

The main aircrafts emissions, which are estimated according to ICAO recommendations is: $\mathrm{CO}_{2}, \mathrm{H}_{2} \mathrm{O}, \mathrm{SO}_{2}$, $\mathrm{CH}_{4}, \mathrm{CO}, \mathrm{C}_{\mathrm{n}} \mathrm{H}_{\mathrm{m}}, \mathrm{NO}_{\mathrm{x}}$ and $\mathrm{SN}$. Taking into account that aircrafts emissions can lead to significant local air pollution that is dangerous for humans, certain emissions norms of the mentioned above substances are introduced for each LTO operation regimes [8].

Levels of emission of each substance depends on the temperature, concentration of fuel and residence time in the combustion chamber. Moreover, the enumerated factors may have the opposite effect on emissions of various substances, which is the main problem in the design of JEs' combustion chambers with low emissions. In addition, due to the variations of these factors on different regimes of engine operation, emissions of pollutants change also differently $[7,9]$.

It is clearly understood that different types of JEs produce different amounts of emissions. Moreover, amount of exhaust gases also depends on the type of JF, mainly its hydrocarbon and element composition. Numerous studies, devoted to estimation of aircrafts emission in most cases do not take into account chemical composition of JFs.

\section{DESCRIPTION OF THE METHOD AND EXPERIMENT REALIZATION}

\section{A. Characteristic Of Fuel Samples}

For fulfilling experimental studies three kind of JF were used. Conventional JF of grade Jet A-1 was studied as a reference fuel. This type of fuels was produced by Polski Koncern Naftowy «ORLEN» (Plok, Poland), and its quality parameters meet requirements of specifications ASTM D1655 [8], Def Stan 91-91 [11].

We have studied two samples of alternative JFs, which were prepared by blending conventional JF and bioadditives based on fatty acids ethyl esters (FAEE) of rapeseed oil (RO). FAEE were produced in the Institute of bioorganic chemistry and petrochemistry of the National Academy of Sciences of Ukraine and were specially modified by vacuum distillation according to the method described in in previous studies of authors [12]. Designation of fuel samples used for studying exhaust gases emission is given in table 2 .

TABLE II.

DESCRIPTION OF FUEL SAMPLES USED FOR EMISSIONS ESTIMATION

\begin{tabular}{c|l|c}
\hline No & \multicolumn{1}{|c|}{ Sample description } & \multicolumn{1}{|c}{$\begin{array}{c}\text { Sample } \\
\text { designation }\end{array}$} \\
\hline 1 & Jet fuel of grade Jet A-1 & $\mathrm{JF}$ \\
\hline 2 & $\begin{array}{l}\text { Jet fuel blended with } 10 \% \text { of rapeseed } \\
\text { oil FAEE bio-additive }\end{array}$ & $\mathrm{JF}+10 \%$ FAEE \\
\hline 3 & $\begin{array}{l}\text { Jet fuel blended with } 20 \% \text { of rapeseed } \\
\text { oil FAEE bio-additive }\end{array}$ & $\mathrm{JF}+20 \%$ FAEE \\
\hline
\end{tabular}

Physical-chemical and operation properties of these alternative JFs were studied in the previous works of the authors and are described in details $[13,14]$. The basic characteristics of studied fuel sample are presented in table 3.

TABLE III.

THE COMPARATIVE CHARACTERISTICS OF QUALITY PARAMETERS OF JF OF GRADE JET A-1, AND JFS BLENDED WITH FAEE BIO-ADDITIVES

\begin{tabular}{|c|l|c|c|c|}
\hline No & \multicolumn{1}{|c|}{ Parameter } & $\begin{array}{c}\text { JF } \\
\text { Jet A-1 } 1\end{array}$ & $\begin{array}{c}\text { JF } \\
+10 \% \\
\text { FAEE }\end{array}$ & $\begin{array}{c}\text { JF } \\
+20 \% \\
\text { FAEE }\end{array}$ \\
\hline 1 & Density at $t=20^{\circ} \mathrm{C}, \mathrm{kg} / \mathrm{m}^{3}$ & 794.03 & 804.11 & 811.81 \\
\hline 2 & Fractional composition: & & & \\
& $t_{\text {i.b.b }},{ }^{\circ} \mathrm{C}$ & 155.22 & 156.11 & 155.99 \\
& $10 \%$ recovery at $t,{ }^{\circ} \mathrm{C}$ & 169.15 & 168.12 & 169.22 \\
& $50 \%$ recovery at $t,{ }^{\circ} \mathrm{C}$ & 186.2 & 188.46 & 193.53 \\
& $90 \%$ recovery at $t,{ }^{\circ} \mathrm{C}$ & 217.13 & 249.1 & 340.66 \\
& $98 \%$ recovery at $t,{ }^{\circ} \mathrm{C}$ & 243.44 & 346.94 & 348.76 \\
\hline 3 & Kinematic viscosity, $\mathrm{mm}^{2} / \mathrm{s}$, at $t:$ & & & \\
& $-20{ }^{\circ} \mathrm{C}$ & 3.292 & 4.027 & 4.957 \\
& $20{ }^{\circ} \mathrm{C}$ & 1.5 & 1.734 & 2.025 \\
\hline 4 & Flash point, ${ }^{\circ} \mathrm{C}$ & 43 & 44.5 & 45.5 \\
\hline 5 & Pour point, ${ }^{\circ} \mathrm{C}$ & -59 & -57 & -55 \\
\hline 6 & Net heat of combustion, $\mathrm{kJ} / \mathrm{kg}$ & 43218 & 42595 & 41971 \\
\hline 7 & Scuffing load, $\mathrm{N}$ & 511 & 680 & 794 \\
\hline 8 & Copper strip test & $1 \mathrm{a}$ & $1 \mathrm{a}$ & $1 \mathrm{a}$ \\
\hline
\end{tabular}


Levels of aircrafts emissions may be determined applying two approaches: experimentally - using special measuring equipment and analytically - calculating, having a set of initial data. However, the first approach is used very rarely, because the experimental equipment is usually available for JE and aircraft producers, moreover, it is very expensive and complex in operation. That is why analytical approach is applied in most cases.

The level of emissions was calculated according to methodology described in $[1,8]$. It is evaluated in grams of pollutant per cycle for $1 \mathrm{kN}$ of take-off thrust and determined by (1):

$$
\frac{M_{j}}{R_{t . t h}}=\sum_{i=1}^{4}\left(E I_{j}\right)_{i} \frac{G_{i} \tau_{i}}{R_{t . t h .}}=\frac{1}{3600} \sum_{i=1}^{4}\left(E I_{j}\right)_{i} G_{S} \bar{R}_{i} \tau_{i}
$$

where:

$M_{\mathrm{j}} \quad-$ mass of pollutant $j$, emitted during standard LTO cycle that consists of $i$ regimes, $\mathrm{g}$,

$R_{\text {t.th. }}-$ take-off thrust, $\mathrm{kN}$,

$E I_{\mathrm{j}}-$ emission index (EI) of pollutant, $\mathrm{g} / \mathrm{kg}$ of fuel,

$G_{\mathrm{i}}-$ fuel flow, $\mathrm{kg} / \mathrm{s}$,

$\tau_{\mathrm{i}} \quad-$ duration of $i$ regime, $\mathrm{s}$,

$G_{\mathrm{s}}-$ specific fuel consumption, $\mathrm{kg} / \mathrm{N} \mathrm{h}$,

$\bar{R}_{\text {i }}-$ relative thrust.

Relative thrust may be found according to (2):

$$
\bar{R}_{i}=\frac{R_{i}}{R_{t . t h}}
$$

where:

$R_{\mathrm{i}} \quad-$ thrust at $i$ regime, $\mathrm{kN}$.

$R_{\text {t.th. }}-$ take-off thrust, $\mathrm{kN}$.

In case when real (measured) FF is known this formula may be simplified (3):

$$
M_{j}=\sum_{i=1}^{4} E I_{j} \cdot G_{i} \cdot \tau_{i}
$$

where:

$E I_{\mathrm{j}}$ - emission index (EI) of pollutant, $\mathrm{g} / \mathrm{kg}$ of fuel,

$G_{\mathrm{i}}-$ fuel flow, $\mathrm{kg} / \mathrm{s}$,

$\tau_{\mathrm{i}} \quad-$ duration of $i$ regime, $\mathrm{s}$.

From the formula above it is seen that level of emissions depends on the efficiency of combustion chamber that is characterized by EI $E I_{\mathrm{j}}$ and on specific fuel flow (FF) $G_{\mathrm{s}}$ at each regime of the LTO cycle.

Taking into consideration typical technical requirements of ICAO to JFs, the quantities of products of complete fuel combustion may be calculated using equations of chemical reaction of burning. The products of complete fuel combustion include $\mathrm{CO}_{2}, \mathrm{H}_{2} \mathrm{O}$, and $\mathrm{SO}_{2}$. The equation of chemical reaction of complete oxidation of fuel (complete combustion) is considered to be stoichiometric $[1,8]$.

The reaction of complete combustion of carbon has the following form (4):

$$
\mathrm{C}+\mathrm{O}_{2} \rightarrow \mathrm{CO}
$$

Taking into account that the molecular mass of carbon (C) is equal to 12 and molecular mass of oxygen $\left(\mathrm{O}_{2}\right)$ is equal to 32 , we can introduce coefficients of reaction and calculate EI of $\mathrm{CO}_{2}$ as following (6):

$$
E I_{\mathrm{CO}_{2}}=\frac{11}{3} \cdot m_{\mathrm{C}}
$$

where:

$m_{\mathrm{C}}-$ content of carbon in fuel, $\%(\mathrm{~m} / \mathrm{m})$.

Analogously the reaction of complete combustion of hydrogen may be written (7):

$$
2 \mathrm{H}_{2}+\mathrm{O}_{2} \rightarrow 2 \mathrm{H}_{2} \mathrm{O}
$$

Taking into account that the molecular mass of hydrogen $(\mathrm{H})$ is equal to 1 and molecular mass of oxygen $\left(\mathrm{O}_{2}\right)$ is equal to 32 , we can introduce coefficients of reaction and calculate $\mathrm{EI}$ of $\mathrm{H}_{2} \mathrm{O}$ as following (9):

$$
E I_{H_{2} \mathrm{O}}=9 \cdot m_{\mathrm{H}}
$$

where:

$m_{\mathrm{H}}-$ content of hydrogen in fuel, $\%(\mathrm{~m} / \mathrm{m})$.

Analogously the reaction of complete combustion of sulfur may be written (10):

$$
\mathrm{S}+\mathrm{O}_{2} \rightarrow \mathrm{SO}_{2}
$$

Taking into account that the molecular mass of sulfur (S) is equal to 32 and molecular mass of oxygen $\left(\mathrm{O}_{2}\right)$ is equal to 32, we can introduce coefficients of reaction and calculate $\mathrm{EI}$ of $\mathrm{SO}_{2}$ as following (9):

$$
E I_{\mathrm{SO}_{2}}=2 \cdot m_{\mathrm{S}}
$$

where:

$m_{\mathrm{S}}-$ content of sulfur in fuel, $\%(\mathrm{~m} / \mathrm{m})$.

These calculations of EIs are maximal since they correspond to complete combustion of fuel. Its error at existing combustion efficiency values usually does not exceed $2 \%$. Formulae for calculating EIs of $\mathrm{CO}_{2}, \mathrm{H}_{2} \mathrm{O}$, and $\mathrm{SO}_{2}$ require data on mass ratio of hydrogen, carbon and sulfur in fuels [15]. These data are presented in Table 4. Elemental composition of conventional JF is statistical and may be found in [16]. The content of carbon and hydrogen in bio-additives was calculated according to the results of its' chromatograph analysis. The content of sulfur was determined according to the standard method, described in $[17,18]$.

TABLE IV.

ELEMENTAL COMPOSITION OF JF AND BIO-ADDITIVES SAMPLES [1]

\begin{tabular}{l|c|c|c|c}
\hline \multirow{2}{*}{$\begin{array}{c}\text { Designation of } \\
\text { fuel sample }\end{array}$} & \multicolumn{4}{|c}{ Content of chemical elements in fuel,\% } \\
\cline { 2 - 5 } & $\mathrm{C}$ & $\mathrm{H}$ & $\mathrm{S}$ & $\mathrm{O}$ \\
\hline $\begin{array}{l}\text { Jet fuel of } \\
\text { grade Jet A-1 }\end{array}$ & 84.975 & 14.0 & 0.025 & - \\
\hline $\begin{array}{l}\text { Modified } \\
\begin{array}{l}\text { FAEE of } \\
\text { rapeseed oil }\end{array}\end{array}$ & 76.889 & 12.095 & 0.0085 & 11.0075 \\
\hline
\end{tabular}

In order to predict $\mathrm{NO}_{\mathrm{x}}$ emissions, basing on generalization of experimental data, we have used the dependence on residence time in the combustion chamber $\tau_{c}$ and turbine inlet temperature $t_{\mathrm{t} \text {.in. }}$ that mostly determines temperature of fire, AFR $\alpha_{c . z .}$ in combustion zone and degree of mixture distortion [1].

Thus, EI of $\mathrm{NO}_{\mathrm{x}}$ was calculated according to (10):

$$
E I_{N O_{x}}=\left(0,06+0,005 \cdot \tau_{c}\right) \cdot e^{0,00736 \cdot t_{\text {t.in }}}
$$

where: 
$\tau_{\mathrm{c}} \quad-$ fuel-air mixture (FAM) residence time in the combustion chamber before combustion, $\tau_{\mathrm{c}}=$ $2 \div 10 \mathrm{~ms}$,

$t_{\text {t.in. }}-$ turbine inlet temperature.

Within the scope of this study the average value of $\tau_{c}$ was taken $-\tau_{c}=6 \mathrm{~ms}$. From the literature sources it is known that the value of turbine inlet temperature $t_{\text {t.in. }}$ is usually higher than jet pipe temperature $t_{\text {j.p. }}$ on $\sim 200{ }^{\circ} \mathrm{C}$. Absence of the dependence of $\mathrm{NO}_{\mathrm{x}}$ emissions on pressure in the combustion chamber is explained by the stability of pressure during oxidation reaction of nitrogen $[4,5]$.

\section{ESTIMATION OF EMISSION INDICES OF AIRCRAFT EXHAUST GASES}

\section{A. Estimation of $\mathrm{CO}_{2}$ emissions}

Using the data from Table 4 mass ratio of carbon, hydrogen and sulfur in samples of JF and JF blended with $10 \%$ and $20 \%$ of modified FAEE bio-additives were derived (Table 5).

TABLE V.

MASS RATIO OF CHEMICAL ELEMENTS IN FUEL SAMPLES

\begin{tabular}{c|c|c|c|c}
\hline \multirow{2}{*}{$\begin{array}{c}\text { Designation of } \\
\text { fuel sample }\end{array}$} & \multicolumn{4}{|c}{ Content in fuel samples, \% (v/v) } \\
\cline { 2 - 5 } & $\mathrm{C}$ & $\mathrm{H}$ & $\mathrm{S}$ & $\mathrm{O}$ \\
\hline $\mathrm{JF}$ & 84.975 & 14.0 & 0.025 & - \\
\hline $\begin{array}{c}\mathrm{JF}+10 \% \\
\text { modified FAEE }\end{array}$ & 84.1668 & 13.7095 & 0.02335 & 1.1008 \\
\hline $\begin{array}{c}\text { JF+ 20\% } \\
\text { modified FAEE }\end{array}$ & 83.3586 & 13.419 & 0.0217 & 2.2015 \\
\hline
\end{tabular}

EI of $\mathrm{CO}_{2}$ was calculated using data from the table above by the formula (5). The results of calculation are presented on Fig. 2.

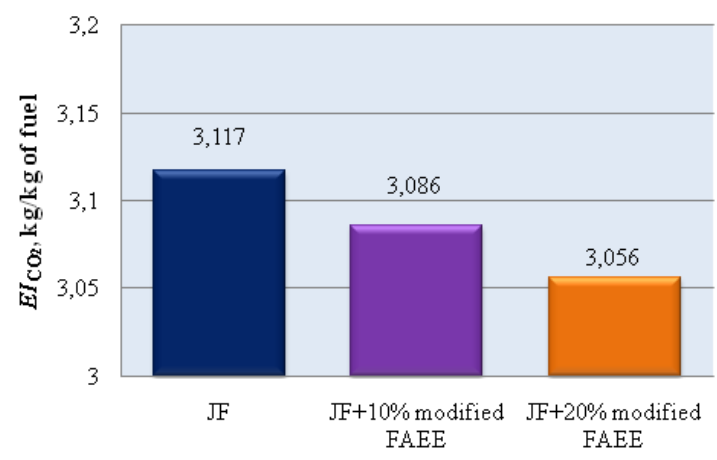

Figure 2. EI of $\mathrm{CO}_{2}$ during combustion of tested fuel samples

It was found that combustion of JFs blended with FAEE bio-additives in quantities $10 \%$ and $20 \%(\mathrm{v} / \mathrm{v})$ results in lower values of $\mathrm{CO}_{2}$ emissions comparing to combustion of conventional fuel. This may be explained by differences in chemical and element composition of RO bio-additives and conventional JF. Typical JF contains about $85 \%$ of carbon in its composition. At the same time bio-additives contain less than $77 \%$ of carbon. It means that adding modified FAEE bio-additives into JF decreases total content of carbon in fuel blends. Thus in a result of blended JFs combustion, which contain $20 \%$ of bio-additives, the amount of $\mathrm{CO}_{2}$ emissions may be decreased by $1.96 \%$. Here special attention should be paid to the comparatively high content of oxygen $(\sim 11 \%)$ in bio-additives, while it is almost absent in JF. Presence of oxygen in fuel allows rising its completeness of combustion. It means that from one side we observe decrease of $\mathrm{CO}_{2}$ emission due to the decrease of carbon content in blended JF. And from other side, increase mass content of oxygen in blended JFs raises completeness of fuel combustion.

\section{B. Estimation of $\mathrm{H}_{2} \mathrm{O}$ emissions}

EI of $\mathrm{H}_{2} \mathrm{O}$ was calculated using data from the table above by the formula (7). The results of calculation are presented on Fig. 3.

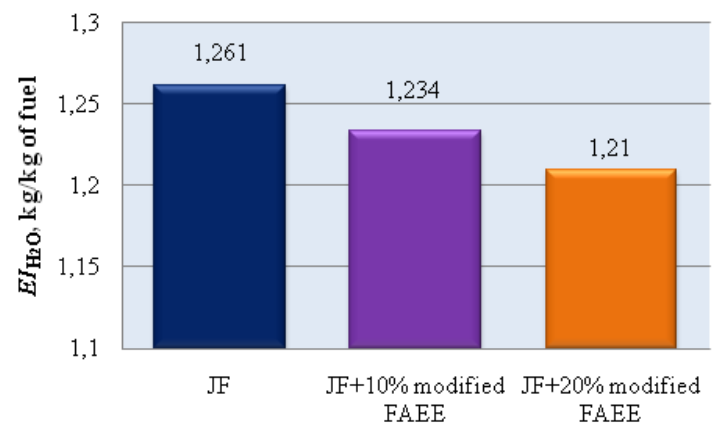

Figure 3. EI of $\mathrm{H}_{2} \mathrm{O}$ during combustion of tested fuel samples

It was found that combustion of JFs blended with FAEE bio-additives in quantities $10 \%$ and $20 \%(\mathrm{v} / \mathrm{v})$ results in lower values of $\mathrm{H}_{2} \mathrm{O}$ emissions comparing to combustion of conventional fuel. This may be also explained by differences in chemical and element composition of RO bio-additives and conventional JF. Typical JF contains about $14 \%$ of hydrogen in its composition. At the same time bio-additives contain about $12 \%$ of hydrogen. It means that adding modified FAEE bio-additives into JF slightly decreases total content of hydrogen in fuel blends. Thus in a result of blended JFs combustion, which contain $20 \%$ of bio-additive, the amount of $\mathrm{H}_{2} \mathrm{O}$ emissions may be decreased by $4.04 \%$.

\section{Estimation of $\mathrm{SO}_{2}$ emissions}

EI of $\mathrm{SO}_{2}$ was calculated using data from the table above by the formula (9). The results of calculation are presented on Fig. 4.

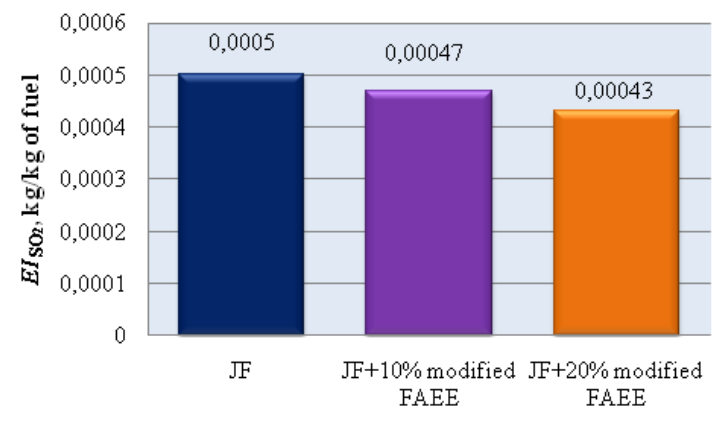

Figure 4. EI of $\mathrm{SO}_{2}$ during combustion of tested fuel samples

It was found that combustion of JFs blended with modified FAEE bio-additives in quantities $10 \%$ and $20 \%$ $(\mathrm{v} / \mathrm{v})$ results in lower values of $\mathrm{SO}_{2}$ emissions, comparing to combustion of conventional fuel. This may be explained 
by that fact that $\mathrm{RO}$ and consequently bio-additives produced from RO contain significantly smaller (negligible) amount of sulfur compounds comparing to conventional JF. It means that adding modified FAEE bioadditives into JF decreases total content of sulfur in fuel blends. Thus $\mathrm{SO}_{2}$ emissions in a result of blended JFs combustion, which contain $20 \%$ of bio-additive, may be decreased by $14.0 \%$.

\section{Estimation of $\mathrm{NO}_{x}$ emissions}

EIs of $\mathrm{NO}_{X}$ were calculated by the formula (10). Taking into account that values of turbine inlet temperature $t_{\text {t.in. }}$. depend on JE operation regime, EIs were calculated for each regime of the standards aircraft LTO cycle. The results of calculations are presented on Fig. 5.

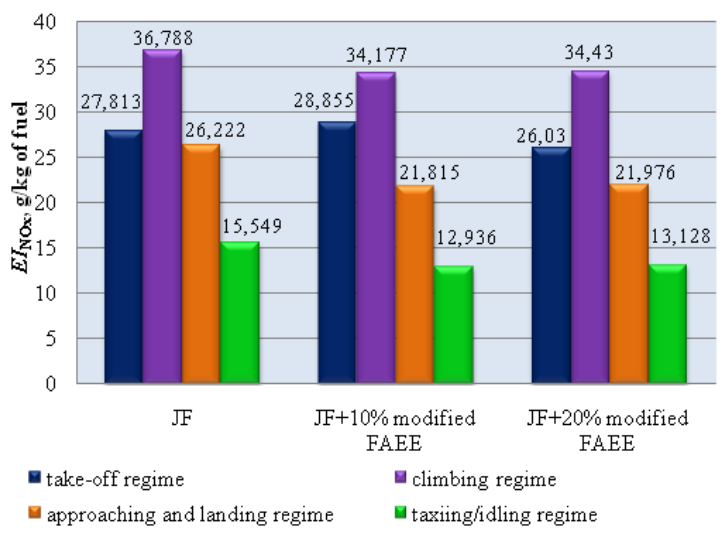

Figure 5. EI of $\mathrm{SO}_{2}$ during combustion of tested fuel samples

The results of calculations have shown that combustion of JFs blended with FAEE bio-additives in quantities $10 \%$ and $20 \%(\mathrm{v} / \mathrm{v})$ results in lower values of $\mathrm{NO}_{\mathrm{X}}$ emissions at all stages of standard LTO cycle comparing to combustion of conventional fuel. However, values of $\mathrm{NO}_{\mathrm{X}}$ emissions almost don't depend on chemical (element) composition of JFs. Both types of fuels - conventional and blended with bio-additives may contain only trace amounts of nitrogen compounds that is not crucial for total $\mathrm{NO}_{\mathrm{X}}$ emissions formation. $\mathrm{NO}_{\mathrm{X}}$ emissions, which are the products of atmospheric nitrogen oxidation, are determined by FAM residence time in combustion chamber and mainly by turbine inlet temperature. Thus, analyzing the experimental data on JE's operation parameters testing, it may be clearly seen that use of JF blends results in lower turbine inlet and jet pipe temperatures comparing to conventional JF. This decrease in temperature consequently affects the amounts of $\mathrm{NO}_{\mathrm{X}}$ emissions at each JE operation regime, i.e. standard LTO cycle regimes. Thus, $\mathrm{NO}_{\mathrm{X}}$ emissions in a result of blended JFs combustion, which contain $20 \%$ of bio-additive, may be decreased during take-off regime by $6.41 \%$, during climbing regime by $7.10 \%$, during approaching and landing regime by $16.81 \%$ and during taxi/idling regime by $16.80 \%$.

\section{COMPARATIVE ANALYSIS OF AIRCRAFT EMISSIONS USING CONVENTIONAL AND ALTERNATIVE JET FUELS}

In order to summarize the obtained results on evaluation of exhaust gases emissions from JE powered by JFs blended with bio-additives and conventional JF the comparative cha racteristic of emission levels was developed.

As it was previously explained emission levels are determined not only by EI of certain pollutant, but also by specific FF at each regime of the LTO cycle and duration of these regimes. Because of that the comparative characteristic of emission levels was developed basing on the total mass of pollutants that is emitted during complete standard LTO cycle (Table 6). Masses of pollutants were calculated using formula (3). The data about net FF were used from the results of JE operation parameters testing. Standard duration time of LTO cycle regimes was taken as it is recommended by ICAO.

TABLE VI.

EMISSION LEVELS OF POLUTTANTS FROM STUDIED FUEL SAMPLES

\begin{tabular}{c|c|c|c}
\hline \multirow{2}{*}{$\begin{array}{c}\text { Mass of } \\
\text { pollutant, } \\
\text { kg/standard } \\
\text { TLO cycle }\end{array}$} & JF & $\begin{array}{c}\text { JF+ 10\% } \\
\text { modified } \\
\text { FAEE }\end{array}$ & $\begin{array}{c}\text { JF+20\% } \\
\text { modified } \\
\text { FAEE }\end{array}$ \\
\cline { 2 - 4 } $\mathrm{CO}_{2}$ & 228.9139 & 177.1479 & 199.9033 \\
\hline $\begin{array}{c}\text { Change of } \\
\text { parameters, } \%\end{array}$ & - & -22.61 & -12.67 \\
\hline $\mathrm{H}_{2} \mathrm{O}$ & 92.6084 & 70.8362 & 79.1501 \\
\hline $\begin{array}{c}\text { Change of } \\
\text { parameter, } \%\end{array}$ & - & -23.51 & -14.53 \\
\hline $\begin{array}{c}\mathrm{SO}_{2} \\
\text { Change of } \\
\text { parameter,\% }\end{array}$ & 0.0367 & 0.0158 & 0.0281 \\
\hline $\begin{array}{c}\text { No } \\
\text { parameter, } \%\end{array}$ & 1.8256 & 1.2854 & 1.4410 \\
\hline
\end{tabular}

Basing on the results of analysis we can make the conclusion that blending conventional JFs with modified FAEE bio-additive in quantity up to $20 \%(\mathrm{v} / \mathrm{v})$ allows decreasing total level of exhaust gases emissions form aircraft JE. The obtained results allowed us concluding that aircraft's emission level is a complex characteristic that depends on both type of JF used (it quality, element and hydrocarbon composition) and JE operation parameters (efficiency of combustion process, FF).

EIs of products of complete JF combustion $-\mathrm{CO}_{2}, \mathrm{H}_{2} \mathrm{O}$ and $\mathrm{SO}_{2}-$ may be predicted (calculated) basing on data about fuel's chemical and element composition and do not require fulfilling JE's bench test. At the same time evaluation of EI of $\mathrm{NO}_{\mathrm{x}}$ requires JE's testing as it is determined by the characteristics of JE operation and calculation is based on these data. The results have shown that increasing ratio of bio-additive in JF blends causes corresponded decreasing of studied pollutants EIs. Adding $20 \%(\mathrm{v} / \mathrm{v})$ of modified FAEE bio-additives may results in decreasing $\mathrm{CO}_{2}$ EI up to $1.96 \%, \mathrm{H}_{2} \mathrm{O}$ EI up to $4.04 \%, \mathrm{SO}_{2}$ EI up to $14.0 \%$, and $\mathrm{NO}_{\mathrm{x}}$ EIs up to $6.41 \%$ during take-off regime and up to $16.80 \%$ during taxi/idling regime.

At the same time evaluation of total mass of pollutants emitted during standard LTO cycle has shown different results. Blending conventional JFs with modified FAEE 
bio-additive generally decreases the total mass of emissions. However adding $10 \%(\mathrm{v} / \mathrm{v})$ of bio-additives allows reaching more reduction of mass of emissions than in case when $20 \%(\mathrm{v} / \mathrm{v})$ of bio-additive is added to conventional JF. This result is explained by that fact that FF, measured during bench tests, was higher for JF blend containing $20 \%$ of bio-additives (especially at idling and 0.8 of nominal regimes of JE operation). Thus, finally we can make the conclusion that adding $10 \%(\mathrm{v} / \mathrm{v})$ of modified FAEE bio-additives may results in decreasing mass of $\mathrm{CO}_{2}$ emissions up to $22.61 \%$, mass of $\mathrm{H}_{2} \mathrm{O}$ emissions up to $23.51 \%$, mass of $\mathrm{SO}_{2}$ emissions up to $56.95 \%$, and mass of $\mathrm{NO}_{\mathrm{x}}$ emission up to $29.59 \%$.

\section{CONCLUSIONS}

Emissions from JE powered with conventional JF and alternative JFs, which contained $10 \%$ and $20 \%$ of modified FAEE bio-additives were evaluated during the study.

Combustion of JFs blended with bio-additives results in lower EI of $\mathrm{CO}_{2}$ comparing to conventional JF that is explained by lower content of carbon and comparatively high content of oxygen in bio-additives, comparing to conventional JF. This allows rising completeness of blended JFs combustion.

Combustion of JFs blended with bio-additives results in lower EI of $\mathrm{H}_{2} \mathrm{O}$ comparing to conventional $\mathrm{JF}$ that is explained by lower content of hydrogen in bio-additives comparing to conventional JF.

Combustion of JFs blended with bio-additives results in lower EI of $\mathrm{SO}_{2}$, comparing to conventional JF that is explained by trace amount of sulfur compounds in bioadditives comparing to conventional JF.

Combustion of JFs blended with bio-additives results in lower EIs of $\mathrm{NO}_{\mathrm{x}}$ at all stages of standard LTO cycle comparing to conventional JF that is explained mainly by lower turbine inlet and jet pipe temperatures comparing to conventional JF. This decrease in temperature consequently affects the amounts of $\mathrm{NO}_{\mathrm{x}}$ emissions at each JE operation regime, i.e. standard LTO cycle regimes.

In the result of emissions evaluation it was concluded that blending conventional JFs with bio-additives allows improving its environmental properties: decreasing amounts of $\mathrm{CO}_{2}, \mathrm{H}_{2} \mathrm{O}, \mathrm{SO}_{2}$ and $\mathrm{NO}_{\mathrm{x}}$ emissions in $\mathrm{JE}$ exhaust gases. Thus it was proved the improvement of environmental properties of JFs by means of introducing RO derived bio-additives.

\section{REFERENCES}

[1] A.V. Yakovlieva, S.V. Boichenko, K. Lejda, O.O. Vovk Modification of jet fuels composition with renewable bioadditives, Center for education literature, Kyiv, 2019.
[2] M. Jacyna, J. Żak, I. Jacyna-Gołda, J. Merkisz, A. MerkiszGuranowska, J. Pielecha, "Selected aspects of the model of proecological transport system", J. KONES Powertrain and Transport, vol. 20, No. 3, pp. 193 - 202, 2013.

[3] L.Q. Maurice, H. Lander, T. Edwards, W.E. Harrison, "Advanced aviation fuels: a look ahead via a historical perspective", Fuel, vol. 80, iss. 5, pp. 747-756, 2001.

[4] B. Gawron, T.Białecki "Impact of a Jet A-1/HEFA blend on the performance and emission characteristics of a miniature turbojet engine", International Journal of Environmental Science Technology, Vol. 15, No. 7: 1501-1508, 2018

[5] B. Gawron, T. Białecki, "Measurement of exhaust gas emissions from miniature turbojet engine". Combustion Engines. 167 (4), 5863. 2016,

[6] D.J. Murphy, C.A.S. Hall, B. Powers, "New perspectives on the energy return on (energy) investment (EROI) of corn ethanol", Environment, Development and Sustainability, vol. 13, iss. 1, pp. 179-202, 2011.

[7] S. Orszulik, Environmental Technology in the Oil Industry, Springer Science \& Business Media, 2013.

[8] Doc 9889 Airport Air Quality Manual. International Civil Aviation Organization, 2011.

[9] Doc 9977. Manual on Civil Aviation Jet Fuel Supply, 2012.

[10]ASTM D1655-11b. Standard Specification for Aviation Turbine Fuels

[11]Defence Standard 91-91. Turbine Fuel, Kerosine Type, Jet A-1. NATO Code: F-35 Joint Service Designation: AVTUR:. Issue 7.

[12]A. Iakovlieva, K. Lejda, O. Vovk, S. Boichenko, I. Skilniuk, "Vacuum Distillation of Rapeseed Oil Esters for Production of Jet Fuel Bio-Additives", Procedia Engineering, vol. 187, pp. 363 370, 2017.

[13] A.V. Yakovlieva, S.V. Boichenko, K. Leida, O.A. Vovk, Kh. Kuzhevskii, "Influence of Rapeseed Oil Ester Additives on Fuel Quality Index for Air Jet Engines”, Chemistry and Technology of Fuels and Oils, vol. 53, iss. 3, pp. 308-317, 2017.

[14]A.V. Yakovleva, S.V. Boichenko, K. Lejda, O.O. Vovk, H. Kuszewski, "Antiwear Properties of Plant-Mineral-Based Fuels for Airbreathing Jet Engines", Chemistry and Technology of Fuels and Oils, vol. 53, iss. 1, pp. 1-9, 2017.

[15] M. H. Azami, M. Savill Comparative study of alternative biofuels on aircraft engine performance, Proceeding of the Institution of mechanical engineers: Journal of aerospace engineering, Vol. 231, Iss. 8, $1509-1521,2016$

[16]L.S. Yanovskyi, N.F. Dubovkin, F.M. Galimov, et al. "Engineering fundamentals of aviation chemmotology", Kazan' university publishing, Kazan', 2005 (in Russian). Л.С. Яновский, Н.Ф. Дубовкин, Ф.М. Галимов и др.: Инженерные основы авиационной химмотологии, Изд-во. Казан. Ун-та, Казань, 2005.

[17] GOST 19121-73. Oil products. Method of determination of sulfur content by burning in lamp (in Russian). ГОСТ 19121-73. Нефтепродукты. Метод определения содержания серы сжиганием в лампе.

[18] Novak-Sedlackova,A. Kurdel,P. Mrekaj, B. Synthesis Criterion of Ergatic Base Complex with Focus on its Reliability, 2017. In: Informatics 2017 : IEEE International Scientific Conference on Informatics. - Danvers (USA) : Institute of Electrical and Electronics Engineers s. 318-321 [print]. - ISBN 978-1-53860888-3 